\title{
Intrinsic Motivation and 21st-Century Skills in an Undergraduate Engineering Project: The Formula Student Project
}

\author{
Iris Talmi ${ }^{1}$, Orit Hazzan ${ }^{2} \&$ Reuven Katz ${ }^{3}$ \\ ${ }^{1}$ Faculty of Mechanical Engineering, Technion, Haifa, Israel \\ ${ }^{2}$ Faculty of Education of Science and Technology, Technion, Haifa, Israel \\ ${ }^{3}$ Faculty of Mechanical Engineering, Technion, Haifa, Israel \\ Correspondence: Orit Hazzan, Faculty of Education of Science and Technology, Technion, Haifa, 32000, Israel. \\ E-mail: oritha@technion.ac.il
}

Received: August 10, 2018

doi:10.5539/hes.v8n4p46

\author{
Accepted: August 31, $2018 \quad$ Online Published: September 17, 2018 \\ URL: https://doi.org/10.5539/hes.v8n4p46
}

\begin{abstract}
The $21^{\text {st }}$ century is characterized by new technological developments and a rapid pace of change, challenging the academy to educate students for a future employment market characterized by change and uncertainty. This market requires practitioners to develop a broad set of skills, so-called "21st-century skills," along with more focused practices within traditional disciplines. The present study explores the mutual relationship between intrinsic motivation and the expression of $21^{\text {st }}$-century skills among students participating in the Formula Student project - an international competition in which participants design and build a racecar while facing challenges such as independent learning, planning, and execution. We found that students' participation in the Formula Student project enables them to practice $21^{\text {st }}$-century skills that they will need in their future workplace; this experience, in turn, helps them meet the psychological need for autonomy, competence, and relatedness which are the basis for intrinsic motivation.
\end{abstract}

Keywords: $21^{\text {st }}$ century skills, capstone course, Formula project, intrinsic motivation, project-based learning (PBL)

\section{Introduction}

"A significant experience, once in a lifetime."

"A huge project that cannot be described in words."

"Worth every minute."

Students describing their experience with the Formula Student project

Formula Student is an international competition organized by the Institution of Mechanical Engineers in partnership with the Society of Automotive Engineers (SAE) (Note 1). In the project, groups of mechanical engineering students from leading technological universities in Europe and beyond design and build a Formula-style racecar, while facing challenges such as independent learning, planning, and execution. The project, which requires extensive knowledge of scientific principles and technical expertise, was established in order to provide engineering students with a rich educational experience and to expose them to engineering culture (Bullen \& Karri, 2002; Gaffney \& Salinas, 1997). The Formula Student project helps prepare students for their unknown future careers by challenging them to face ambiguous problems that have multiple possible solutions rather than one correct answer (Bullen \& Karri, 2002; Gruner, 2014).

Participation in the Formula Student project is not a required component of students' coursework, though some do receive academic credit for participating. Therefore, the question arises, what motivates students to take part in such a demanding, time-consuming, and potentially stressful activity? The present research uses the Formula Student project at one institution, the Technion - Israel Institute of Technology, to examine the sources of students' motivation to engage in such projects. We explore the mutual relationship between intrinsic motivation and the expression of so-called $21^{\text {st }}$-century skills - a set of overarching thinking, working and social competencies such as critical thinking, communication, and teamwork - among 54 participants in the Technion's Formula Student project during the academic year 2014-2015. We find that participation in the Formula project 
enables students to practice $21^{\text {st }}$-century skills that they will need in their future workplace. In turn, this experience fulfills their psychological needs for autonomy, competence, and relatedness, which are the basis for intrinsic motivation.

In Section 2 we review relevant literature on project-based learning, $21^{\text {st }}$-century skills, and intrinsic motivation. Section 3 describes the Formula Student project. In Section 4 we outline our research methodology and sources of quantitative and qualitative data. Section 5 presents the research results. In Section 6 we conclude.

\section{Literature Review}

\subsection{Capstone Projects and Project-Based Learning (PBL)}

The Technion's Formula Student project is based on the principles of a capstone engineering project. Capstone projects allow students to integrate and apply knowledge from prior courses, as well as to identify and learn new knowledge needed for the project (Jones, Epler, Mokri, Bryant \& Paretti, 2013). Capstone projects often, but not necessarily, take place during the final year of an academic program. Students work in teams on an open-ended problem related to their engineering discipline and are required to demonstrate technical, scientific and engineering skills, as well as so-called $21^{\text {st }}$-century skills, such as teamwork, communication, project management, self-directed learning, and ethical practice. Thus, the projects bridge between students' classroom experiences in problem solving and the collaborative design work anticipated for them in industry (Jones et al., 2013). According to the Great Schools Partnership Glossary of Education Reform, "the creative nature of capstone projects, which are typically self-selected by students and based on personal interests, can strengthen student motivation to learn" (Great Schools Partnership, 2014). Participation in engineering capstone courses can help develop social connections among the learning community (student-to-student and student-to-faculty), shape students' identity as future engineers, and improve student retention (Butterfield \& Branch, 2016).

Capstone projects are based on project-based learning (PBL) - a multidisciplinary approach that exposes students to a set of practical tools and approaches, helping them construct new knowledge, understanding, and skills as they build a prototype or a product (Beddoes, Jesiek, \& Borrego, 2010; Cobb, Agogino, Beckman, \& Speer, 2008; Dym, Agogino, Eris, Frey, \& Leifer, 2005; Grant, 2011; Male, Bush, \& Chapman, 2010; Thomas, 2000). PBL focuses on questions or problems that encourage students to address central concepts of the discipline while fostering decision-making and problem-solving skills, autonomy, and responsibility. Towards this end, capstone projects incorporate real-life challenges that focus on authentic problems or questions whose solutions have the potential to be implemented (Grant, 2011; Jones et al., 2013; Thomas, 2000).

\subsection{Twenty-first Century skills}

The enormous changes in the past decade in the global economy are driving demand for employees who are proficient not only in the professional skills demanded by their chosen field, but in a broader set of personal skills and competencies, often called 21 $1^{\text {st }}$-century skills (Binkley et al., 2012; Casner-Lotto \& Barrington, 2006; Duderstadt, 2010; Greenhill 2010; Male et al., 2010). These are sometimes referred to in the education literature as "college and career readiness," "next-generation learning," and "deeper learning," among others (Pellegrino \& Hilton, 2012). Such skills - e.g., oral communication, teamwork, professionalism, critical thinking, adaptability, and interpersonal skills - are crucial if students are to integrate and prosper in the industrial employment market (Casner-Lotto \& Barrington, 2006; Pellegrino \& Hilton, 2012).

The present paper draws on several frameworks presented in the literature dealing with the dialog between higher educational institutions and industry regarding students' preparedness for the needs of the current and future workplace (Binkley et al., 2012; Casner-Lotto \& Barrington, 2006; Pellegrino \& Hilton, 2012). For the data analysis in this paper, these skills were divided into three categories: thinking skills, working skills, and social skills:

- Thinking skills: Critical thinking, problem solving, decision making, self-regulated learning, innovation and creativity, holistic thinking.

- Working skills: Communications (verbal and written), management skills, professionalism, leadership, information and communications technology (ICT).

- Social skills: Interpersonal relationships, collaboration, teamwork.

\subsection{Intrinsic Motivation}

Over the years, research on learning and teaching processes has focused increasingly on student motivation (Pintrich, 2003). Motivation refers to a desire to invest time and effort in an activity, even when it entails difficulty, high costs, and possible failure (Assor, 2001; Ryan \& Deci, 2000a). Motivation is not a stable attribute of an individual, but, rather, is contextual and domain-specific (Linnenbrink \& Pintrich, 2002). Motivational 
theories are concerned with two facets of motivation: energization (what gets individuals moving) and direction (towards what activities or tasks) (Pintrich, 2003). At the empirical level, researchers have examined the effects of a range of motivational variables, including self-efficacy (Bandura, 1994), self-regulation (Pintrich, 2004), interest, and goals (Hidi \& Harackiewicz, 2000).

Researchers define different types of motivation based on the different reasons or goals that prompt action. In general, motivations fall into two broad groups, depending on whether the goals that prompt them are intrinsic or extrinsic (Ryan \& Deci, 2000a; Vansteenkiste, Lens \& Deci, 2006). Intrinsic motivation is based on internal rewards: people are intrinsically motivated to engage in behaviors that they find inherently interesting or enjoyable. Extrinsic motivation is based on external outcomes that are separable from the activity itself, such as obtaining an (external) reward or avoiding a punishment (Ryan \& Deci, 2000a; Niemiec \& Ryan, 2009).

From an educational point of view, clearly, not all aspects of education are inherently interesting or enjoyable in an immediate sense. In such cases, intrinsic motivation is not sufficient and students also need external reasons or incentives to learn (Niemiec \& Ryan, 2009). However, it is well-established in education research that intrinsic motivation fosters creativity and provides a natural basis for learning and development (Niemiec \& Ryan, 2009; Vansteenkiste et al., 2006).

In recent years, researchers have argued that a dichotomous distinction between external and internal factors does not reflect the complex, nuanced origins of motivation, where "external" factors may be internalized and where internal and external factors fall at various points on a continuum (Hidi \& Harackiewicz, 2000; Niemiec \& Ryan, 2009; Ryan \& Deci, 2000a). From this perspective, the aim in the classroom is to promote and strengthen internal factors that energize students to engage in learning. Ryan and Deci (2000b) argue that a motivation to study is enhanced and becomes more self-determined when three basic psychological needs are satisfied: autonomy, competence, and relatedness (Koh et al., 2010; Pintrich, 2003). Autonomy refers to an ability to experience volition and self-regulation, independent from undesired external and internal pressure (Koh et al., 2010; Krapp, 2005; Pintrich, 2003). Competence is an ability to fulfill challenging tasks successfully or efficiently and receive positive feedback from one's social environment (peers and/or instructors) (Koh et al., 2010). And, finally, relatedness refers to the development of secure and fulfilling interpersonal relationships within one's social environment (Koh et al., 2010; Pintrich, 2003). Meeting these psychological needs appears to be essential for optimal functioning of the natural tendency for growth and integration, as well as for constructive social development and personal well-being (Ryan \& Deci, 2000b). Moreover, recent studies suggest that a sense of belonging to the engineering community and social integration (both peer-to-peer and student-to-faculty) improve student retention, which is a big concern in the engineering education community (Butterfield \& Branch, 2016; Marra, Chia-Lin, Bogue \& Pytel, 2015; Marra, Rodgers, Shen \& Bogue, 2012; Ricks et al., 2014; Tuchscherer, Gray \& Gray, 2017).

\section{The Formula Student Project}

The Formula Student competition challenges teams of competitors from engineering programs around the world to design, build, test, and - eventually - race a prototype for a single-seat racecar, following given design specifications. At the Technion, students participate in the project for one, two or three years, with an opportunity to advance over the years to become team leaders. This process enables student-led knowledge transfer from year to year based on the project database and design review files. At the beginning of each academic year, improved technical specifications are defined in order to build a better performing car compared to the previous year.

The Technion Formula Student project team at any time typically includes 40 to 50 students from five academic departments, each studying an academic course on vehicle dynamics. This large group is divided into about 10 sub-teams of three or four students, each responsible for a different capstone project (e.g., aerodynamics simulation and design; mechanical design of the chassis and breaks; design of suspension and wheels; energy, sensors, and control mechanisms; industrial design). The overall project is overseen by a managing team led by a Captain (a graduate student), and including a system engineer, financial manager and marketing manager. The purchasing process is controlled by the Captain and by a faculty member, and the interfaces among teams and integration of their sub-projects are coordinated by the system engineer. Each team has an academic adviser who assists and grades students' performance; mentors from industry also assist. The advisers ensure that the students perform all required analyses and simulations required to meet high academic standards.

Each year's Formula Racer project follows a tight schedule starting in October and ending the following July or August, when the international competition is held. The car itself must be completed and ready for testing by the beginning of May. The period between October and May is characterized by intense work on the car's 
components and processes, including presentations by each of the sub-teams to their advisors and the full project team. Once testing is completed the car is shipped to Europe in time for race day.

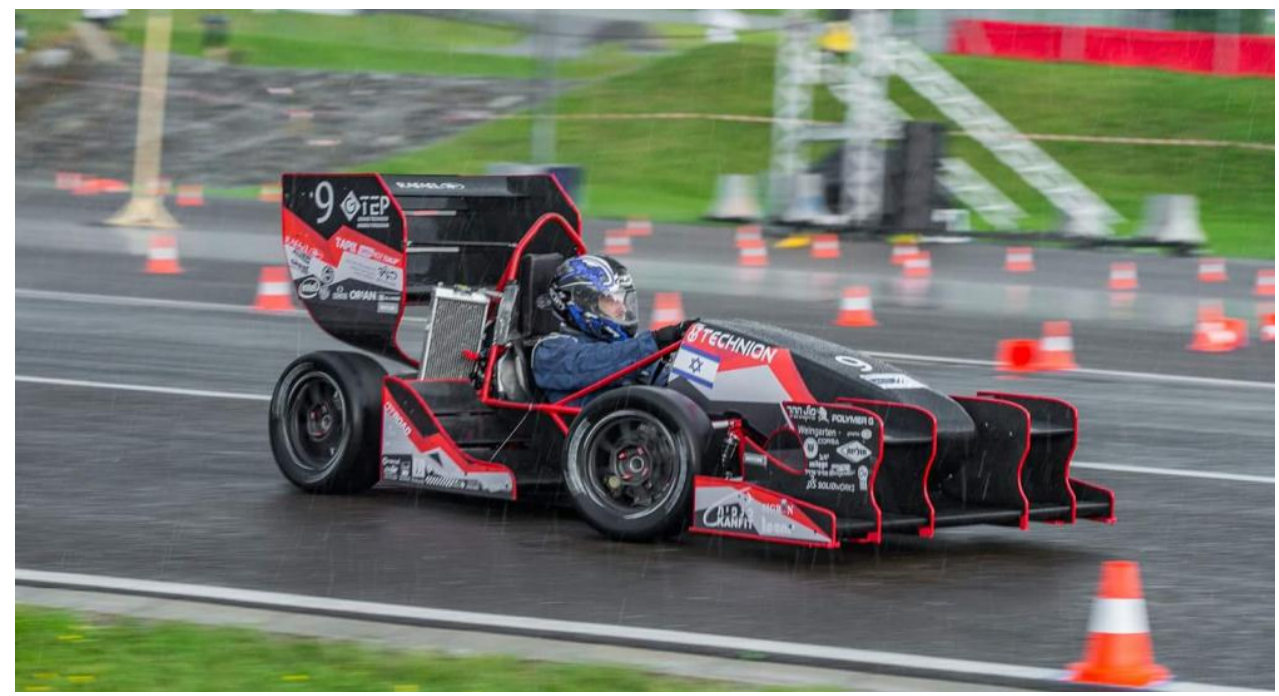

Figure 1. Formula Student project - The Technion Racer 2016

\section{Research Methodology}

\subsection{Research Target and Questions}

The aim of the research is to study the mutual relationship between intrinsic motivation and the expression of $21^{\text {st }}$-century skills by students participating in the Technion's Formula Student project.

From this purpose, the following research questions were derived:

1. How are students motivated to invest time and effort in the project?

2. How are $21^{\text {st }}$-century skills expressed in students' participation in the Technion's Formula Student project?

3. Does the expression of the $21^{\text {st }}$-century skills in the Technion's Formula Student project increase students' motivation to participate in the project? If yes - how?

The research was conducted during one year of the project, from October 2014, when the Formula team was assembled, until September 2015, after the competition ended. A case study methodology was used to understand the perceptions and attitudes of both students and mentors in their natural environment, as a means to elicit a holistic description and explanation of the studied phenomena (Borrego, Douglas \& Amelink, 2009; Merriam, 2002).

Case study research supports multiple methods of data collection, both qualitative and quantitative, including questionnaires, interviews, observations, and artifacts (Baxter \& Jack, 2008; Yin, 2013). In engineering education research, studies increasingly employ qualitative research as a lens through which quantitative findings can be interpreted (Borrego, Douglas \& Amelink, 2009). In accordance, the present study employed a mixed (qualitative and quantitative) methodology.

\subsection{Research Participants}

Fifty-four students from five Technion departments participated in our study. Of these, 35 were taking part in Formula Student for the first time; the other 19 were in their second or (in a few cases) third year of participation. Thirty-eight students (about 70\%) were in the department of Mechanical Engineering; the others were in the departments of Aerospace Engineering, Architecture and Urban Planning, Electrical Engineering, and Industrial Engineering and Management. About half the students received academic credit for their participation. In addition, two mentors from the Technion and two mentors from industry participated in the research.

\subsection{Research Field}

The project workspace, located in the Technion's Mechanical Engineering Building, was the study field, as it was the site of most of the group's activities. 


\subsection{Research Tools}

Data were collected through observations, semi-structured questionnaires, in-depth interviews, reflection field notes, and documents, as described next.

Observations: Two sets of observations were conducted.

- Two observations of 4 hours each were carried out during the students' recruitment interviews, which took place over two days in October. The recruitment interviews were conducted by four project leaders who had participated in the Formula Student project during the previous year.

- Twenty-three observations of 1.5 hours each were conducted during weekly meetings of the project management team. The participant observation strategy was used as it allowed the researcher to be part of the group culture and to gain a closer insight into the group's practices, behaviors, motivations, and emotions (Merriam, 2002).

Questionnaires: Two semi-structured questionnaires were distributed to student participants.

- The first questionnaire was distributed to the 19 veteran participants at the project midpoint, i.e., at the end of the design phase and the beginning of the production phase. The students were asked to grade the 21 st-century skills they had acquired during the project thus far, and to share additional insights regarding their role in the project. These results were used to improve our understanding of the research field and to provide a foundation for the interviews and the second questionnaire. All 19 students returned completed questionnaires.

- The second questionnaire was distributed to all 54 participants at the end of the project, right after the students returned from the international competition. In this questionnaire the students were asked to rank on a $1-5$ scale the degree to which they had acquired specific $21^{\text {st }}$-century skills. They were also asked to explain the reasons for their answer, adding a qualitative dimension to the questionnaire. Twenty students answered the second questionnaire, a response rate of $37 \%$.

Interviews: In-depth interviews were conducted with six of the team leaders, most of whom had participated in the project for at least two years, and who therefore had a broad perspective on the project. In-depth interviews were also conducted with the two academic mentors and the two industry mentors (Merriam, 2002; Yin, 2013). All interviews were recorded and transcribed.

Additional data sources included reflection field notes taken during special events (such as group presentations, the annual exhibition, and the car test drives) and documents and other written materials (such as emails and Facebook posts).

Analysis of the data took place concurrently with data collection, enabling the researchers to fine-tune the research process along the way and to check emerging concepts, categories and themes against the subsequent data. This inductive data analysis strategy guided us in looking for common patterns across the data (Merriam, 2002).

\subsection{Research Validity}

Data triangulation was carried out to validate the findings (Borrego, Douglas \& Amelink, 2009; Merriam, 2002; Yin, 2013). Peer debriefing was also used to reinforce the validity of the research findings (Borrego, Douglas, \& Amelink, 2009).

\section{Research Results - Need for Autonomy, Competence and Relatedness as the Driving Forces of Motivation}

We identified a cyclic process in which the $21^{\text {st }}$-century skills that students acquire and apply while participating in the Formula project lead to the fulfilment of the three basic needs described above - autonomy, competence and relatedness. This, in turn, increases students' intrinsic motivation, leading them to invest more in the project and to further use and practice the $21^{\text {st }}$-century skills. See Figure 2. 


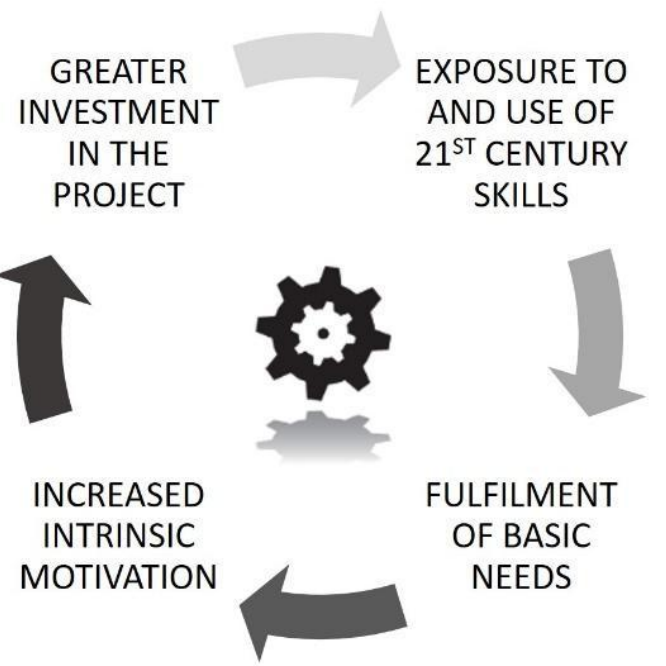

Figure 2. The cyclic process identified in the research

The Formula Student project demands autonomy in the sense that students choose their own role in the project; it calls for competence in accomplishing a challenging set of tasks; and it aims to strengthen relatedness, in the sense of exposing students to engineering culture and making them feel part of the wider engineering community through their work in an engineering team. For each case, we present data to convey how project-based learning fosters learners' motivation by supporting the acquisition and use of $21^{\text {st }}$-century skills that help meet these three basic needs. Table 1 presents the specific $21^{\text {st }}$-century skills expressed in the Formula project, according to the need whose fulfilment they most support.

Table 1. The role of thinking skills, working skills and social skills in meeting students' needs for autonomy, competence, and relatedness

\begin{tabular}{lcclc}
\hline & Autonomy & Competence & Relatedness \\
\hline Thinking & $\circ$ & Decision making & $\circ$ & Critical thinking \\
skills & $\circ \quad$ Self-regulated & $\circ$ & Innovation / Creativity & \\
& & learning & $\circ$ & Holistic thinking \\
& & $\circ$ & Problem solving \\
Working & & $\circ$ & Communication (verbal \& & \\
skills & & written) & \\
& & $\circ$ & Management skills & \\
& & $\circ$ & Professionalism & \\
& & & Leadership & \\
& & & Information and & Interpersonal \\
Social & & Communications & relationships \\
skills & & Technology (ICT) & Collaboration / \\
& & & Ethics & Teamwork \\
\hline
\end{tabular}

\subsection{Autonomy}

As noted above, autonomy is core to the Formula Student project, in that students participate voluntarily and at a level of their choice: they decide for themselves whether to take part, and once they sign up, they choose their own role in the project and their level of responsibility. Our analysis suggests that participation enables students to experiences $21^{\text {st }}$-century skills - and in particular, thinking skills - which in turn promote this sense of autonomy.

Two thinking skills which help students fulfil the need for autonomy were highlighted: self-regulated learning and decision making. In the final questionnaire, in which students were asked to indicate the degree to which 
they applied different $21^{\text {st }}$-century skills during their participation in the project on a 5-point scale, self-regulated learning $(\mathrm{Av} .=4.5, \mathrm{SD}=0.6)$ and decision making $(\mathrm{Av} .=4.6, \mathrm{SD}=0.49)$ received the highest ratings.

Self-regulated learning featured prominently in our interviews with students and mentors. For instance, one veteran student, who was on the team which selected the participants in the project, described one of the candidates' perceptions about the opportunities that the project would provide him: "I would love to learn every aspect, every function needed. Get a project, sit down to think and perform." One of the industry mentors described this skill from a broader perspective: "There's a hierarchy of skills, not necessarily engineering skills. Self-regulated learning - due to the time pressure, you need to calculate risks in order to advance the project. [...] We know that the learning here is huge. Learning strategies is more important than the actual content. Skills are more important than content. Content will be learned eventually, in a day, a week, a month or a year."

For its part, decision making is clearly inherent to nearly every aspect of the project design and development. For instance, early in the design phase, the team had to make a decision about changes to be implemented in the configuration of the car from the previous year, and specifically, how to reduce the car's weight from $215 \mathrm{Kg}$ in the old version to under $150 \mathrm{Kg}$. This was a major decision that would impact the car's performance, but it carried risks. One approach the team considered was replacing the engine with a smaller one and reducing the diameters of the wheels from 13" to 10 ". However, this would have reduced the ratio of power to weight from 0.39 to $0.35[\mathrm{HP} / \mathrm{Kg}]$ while not increasing the ratio of torque to weight from its previous level of $0.3[\mathrm{Nm} / \mathrm{Kg}]$. Ultimately, the team decided to reduce the weight by making the car lower to the ground (reducing the height from the ground of the car's center of gravity from $250 \mathrm{~mm}$ to $200 \mathrm{~mm}$ ) while keeping the engine and wheels the same size. See Figures 3A and 3B.

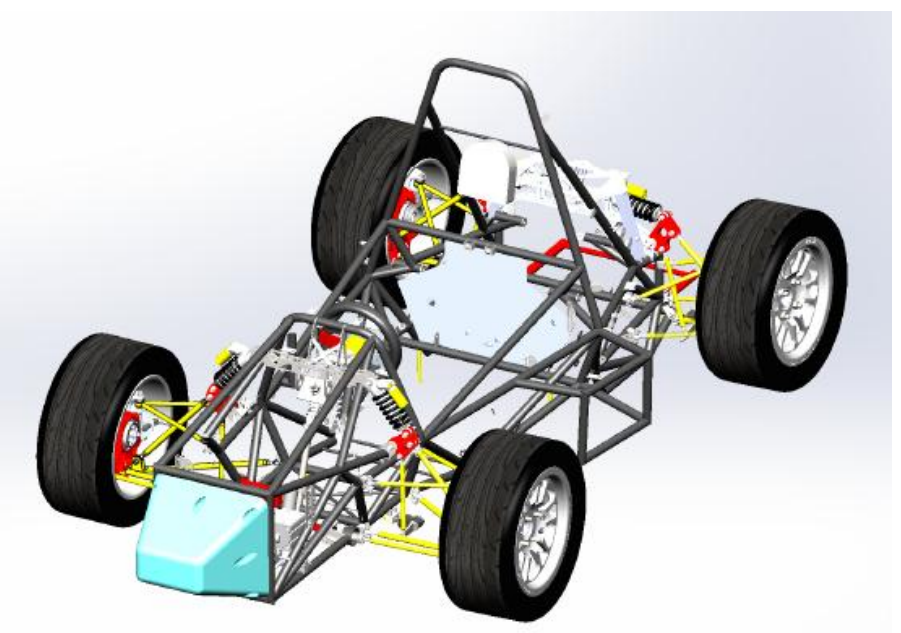

Figure 3A. The old configuration of the Formula Student racer

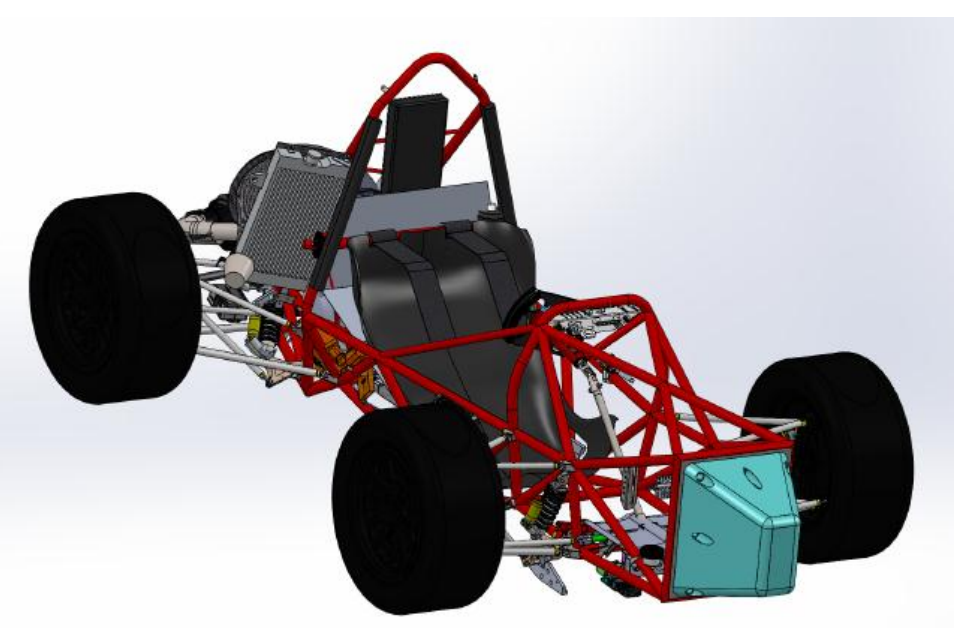

Figure 3B. The new configuration of the Formula Student racer 
In our interviews, one of the industry mentors described this process as follows: "Here they experience many things that are new to them. They have a lot of freedom to choose whether to do it one way or another depending on the constraints."

\subsection{Competence}

The psychological need for competence is reflected in students' desire to succeed in their assignments and receive positive feedback and respect from their peers and mentors.

Table 2 presents students' ratings of the thinking and working skills expressed while participating in the Formula project that support fulfilment of the basic need for competence. All skills were rated at 3.45 or above, and over half were rated as "high" ( 4 or above).

Table 2. Acquired skills with respect to the basic need for competence

\begin{tabular}{llll}
\hline Category & Skill & Average rating (1-5) & SD \\
\hline Working skills & Written communication & 3.45 & 1.03 \\
Thinking skills & Innovation & 3.66 & 1.15 \\
Working skills & Leadership & 3.75 & 1.57 \\
Working skills & Ethics at work & 3.85 & 1.61 \\
Working skills & Verbal communication & 3.95 & 1.37 \\
Working skills & Professionalism & 4.1 & 1.58 \\
Thinking skills & Holistic thinking & 4.2 & 1.73 \\
Working skills & Management skills & 4.2 & 1.73 \\
Thinking skills & Creativity & 4.25 & 1.95 \\
Thinking skills & Critical thinking & 4.25 & 1.82 \\
Working skills & Information and Communications Technology (ICT) & 4.35 & 1.98 \\
\hline
\end{tabular}

The qualitative data support the quantitative results for the thinking and working skills identified. Here we provide some representative comments and observations.

\section{Thinking Skills}

With respect to the thinking skills, both critical thinking and holistic thinking (i.e., looking at the whole picture) recurred frequently in the qualitative data. For instance, in his answers to the final questionnaire, one of the students described this importance of critical thinking this way: "Creating drawings, analyzing performance and manufacturing are the bread and butter of a mechanical engineer." Meanwhile, one of the university mentors captured the role of holistic thinking: "Conducting a survey [literature review], examining what is being done around the world, not only in the field of Formula Student, but in the field of engines, what the global trends are. [...] I mean they have to learn a new language."

\section{Working Skills}

As can be seen from Table 2, the need for competence is fulfilled by a relatively high number of working skills, with management skills among the highest rated. Indeed, all students participating in the project, and particularly team leaders, had to practice people- and time-management skills. The organizational structure of the Formula Student project itself promotes the development of management skills among participants (Figure 4).

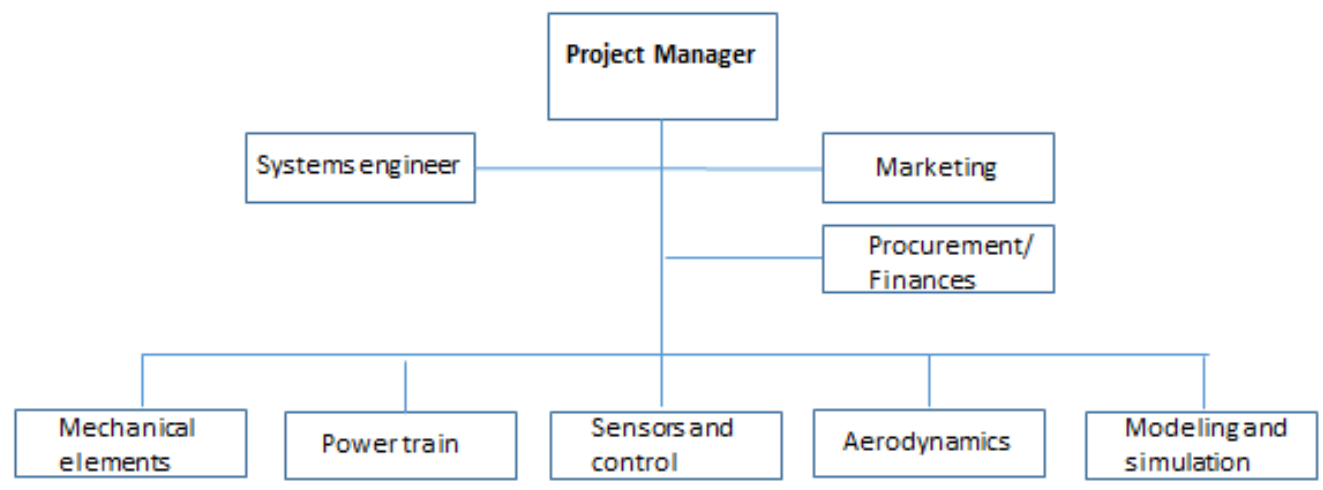

Figure 4. Formula Student project - Organizational structure 
The potential contribution of the Formula project to student management skills is expressed in students' and team leaders' written and verbal reflections. For instance, as one of the team leaders wrote in the final questionnaire: "This is my fourth year [and last one at the Technion], but I decided to participate [in the project] for another year. My goal is [to gain] management experience, specifically, to gain some management experience that I lack." Another team leader said in an interview: "One of the things I understand now better is how to manage people and how to be part of the management and decision making processes, to think deeply about each decision $[\ldots] . "$

Clearly, the students who fill top managerial roles gain the most meaningful management experience, but the collaborative, team-based structure of the project means that other students also acquire management skills simply by virtue of their active participation. As one student explained in the questionnaire: "[The project] contributed significantly to my managerial and organizational skills. It taught me a lot about purchasing processes and about working with suppliers."

We observed a natural "filtering" process after students' first year of participation in the project. Students who emphasize the contribution of the project to their future professional career tend to be those who continue for another year. Students who are more focused on the project's intensity over the short term often decide to leave the project after one year. Only a few students choose to stay in the project for a third year in order to become project managers or system engineers.

A decision to participate in the project for more than one year and to proceed to a higher management role may be explained by a set of intrinsic motivations. These include an understanding of the project's contribution to their professional career and their volition to improve their management skills, as presented in Figure 5.

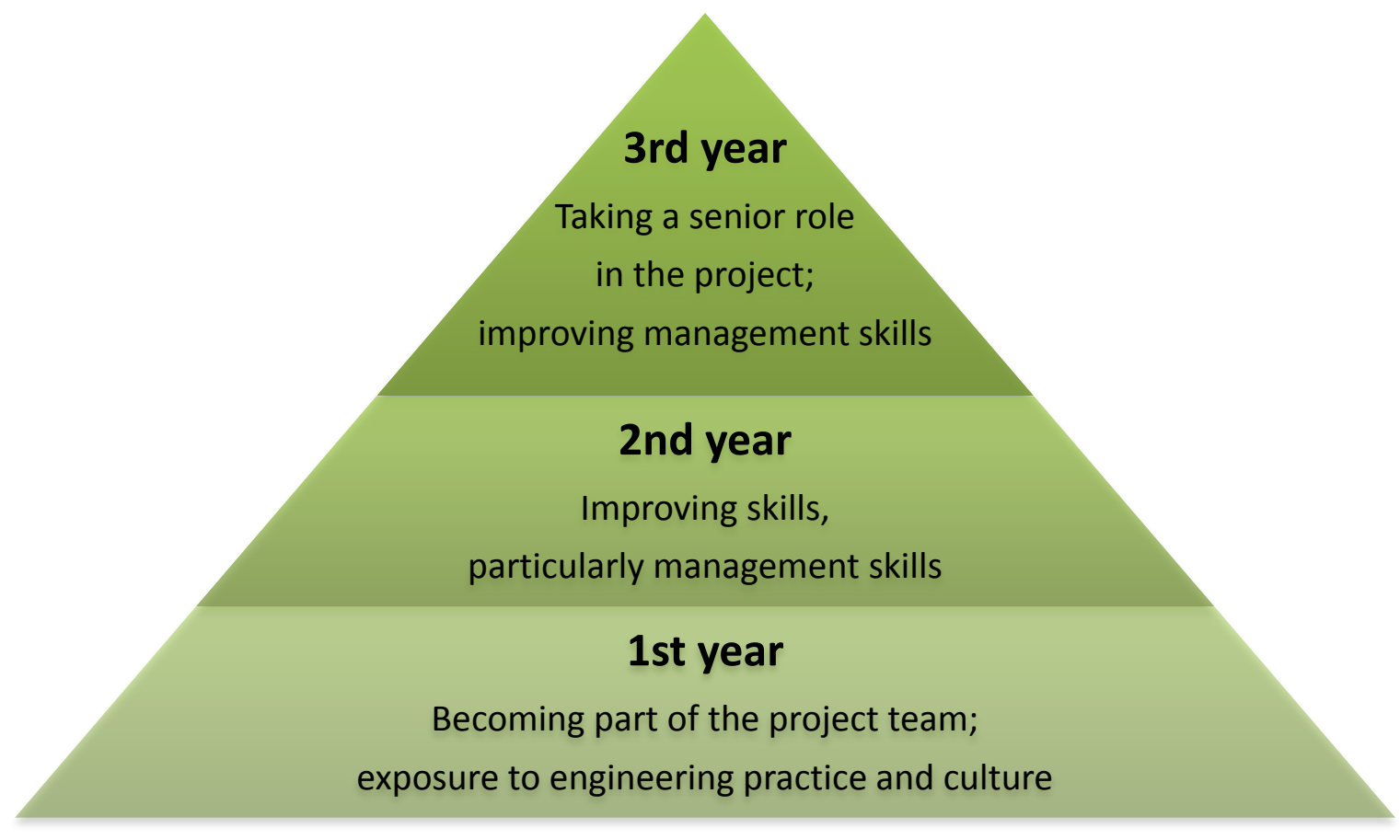

Figure 5. Students' intrinsic motivation factors to participate in the project for more than one year

Participants who go on to become leaders of the various sub-teams in their second year of participation tend to have good time-management skills and to be high academic achievers. Indeed, many continue on to graduate studies. In our data, most team leaders who were participating in the project for a second year, this time in a management role, addressed the improvement in their time management skills relative to previous year(s). Here is an illustrative quote from one team leader: "I feel the lack of time so it is not easy at all. On the other hand, it caused me to improve my time management and thus, my grades this year are improving.... Since I've become [involved] in the project, I have something that I love and want to do, and I want to make the time for it. This causes me to finish my homework the minute I get it and I do not leave it to the last minute, like I used to." 


\subsection{Relatedness}

One of the functions of the Formula Student project is to give students a sense of being part of the larger engineering community as well as their current learning community. Two $21^{\text {st }}$-century skills that support relatedness were highly rated by participants, both of them social skills - namely interpersonal relationships $(\mathrm{AV} .=4.15, \mathrm{SD}=1.99)$ and collaboration/teamwork $(\mathrm{AV} .=4, \mathrm{SD}=1.51)$. It should be noted that interpersonal relationships were forged not only within the team, but also with role-holders at the Technion and in industry (e.g., sponsors, suppliers, and more).

The practical application of teamwork is apparent in Figures 6 and 7, which show stages in the actual construction of the car.

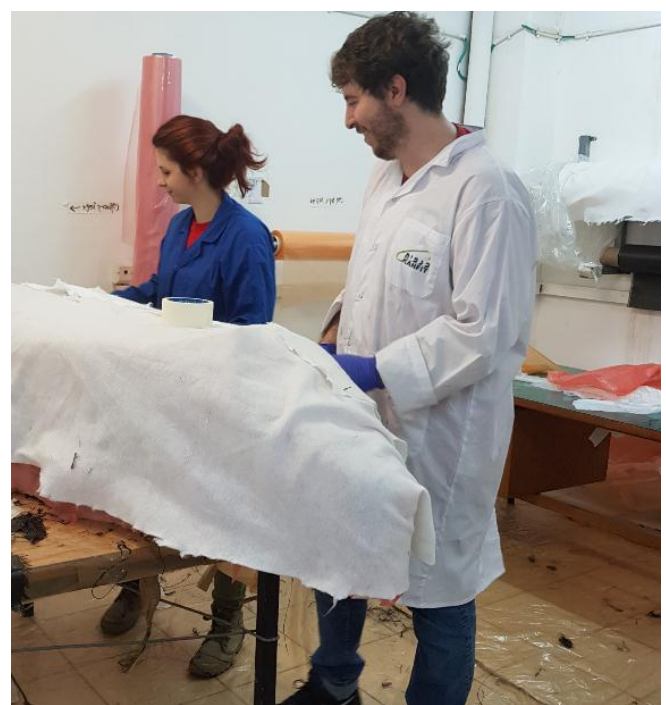

Figure 6. Production of carbon parts

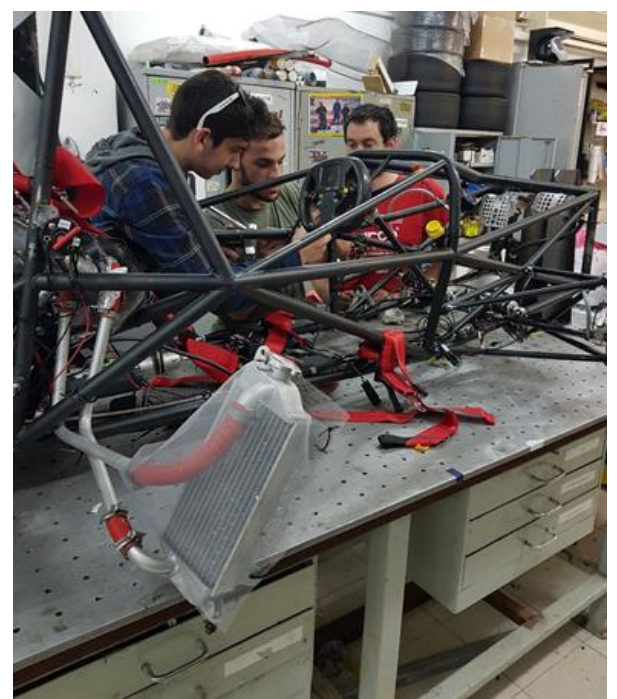

Figure 7. Car assembly

The centrality of teamwork and its role in fulfilling the need for relatedness was apparent throughout the data analysis. For instance, during the student candidacy interviews, one interviewee said: "I'm good at teamwork, at raising group morale, organizing things, making it fun. I would like to help with whatever is needed, to be part of the project." Another student explicitly linked teamwork to the nature of professional engineering in his final questionnaire: "I got to learn a completely new field. I tried something I did not have any previous experience with, got to troubleshoot the system failures, and, of course, the great teamwork. All these things are directly related to the profession that I'm learning." Similar comments came from the team mentors. As one industry mentor put it, "I would call it teamwork skills, skills for working in the project. Skills for taking the issue beyond the technical question and adapting it to life constraints." And finally, from one of the academic faculty involved in the project: "An engineer cannot be closed in a room and work on a project alone. He should be a social person, especially if he is a team leader. It is more complex: guiding people; the ability to encourage and motivate people."

\section{Conclusions}

The research presented in this paper focuses on students' intrinsic motivation to participate in the Formula Student project, despite the required substantial investment of time and, often, lack of formal academic rewards. Intrinsic motivation is increasingly recognized as central in research on learning and teaching processes (Casner-Lotto \& Barrington, 2006; Pellegrino \& Hilton, 2012; Pintrich, 2003). The fulfillment of three basic psychological needs - autonomy, competence, and relatedness - forms the basis for the emergence of students' intrinsic motivation (Koh et al., 2010; Pintrich, 2003; Ryan \& Deci, 2000b).

To the best of our knowledge, no previous study has found a link between students' intrinsic motivation and the acquisition of $21^{\mathrm{st}}$-century skills while participating in an engineering project. We found a mutual relationship between students' intrinsic motivation to participate in the project and their acquisition and strengthening of $21^{\text {st }}$-century skills. In brief, participation in the Formula Student project builds students' $21^{\text {st }}$-century skills, which, in turn, fulfill their psychological needs, enhancing their intrinsic motivation to participate.

As our study indicates, the Formula Student project provides students a unique opportunity in a supportive 
engineering atmosphere to express $21^{\text {st }}$-skills, including thinking, working, and social skills, that directly lead to the fulfilment of the above three basic needs. Specifically, the need for autonomy, reflected in students' ability to make independent decisions such as what role to take in the project, was fulfilled by students' expression of thinking skills such as decision making and self-regulated learning. The need for competence, seen in students' desire to successfully accomplish their assignments and to receive positive feedback from their peers and mentors, was fulfilled by students' expression of $21^{\text {st }}$-century thinking skills, such as critical thinking, and working skills, such as management. Finally, the need for relatedness, which represents students' need to be part of their learning community and engineering culture, was fulfilled by the opportunity that the Formula Student project provided to express $21^{\text {st }}$-century social skills, such as teamwork.

We conclude by returning briefly to our research questions. Students' motivation to invest in the Technion's Formula Student project is explained by the opportunity to meet their basic needs for autonomy, competence and relatedness (Question 1). Students' participation in the project enables them to express three groups of $21^{\text {st }}$-century skills, namely thinking skills, working skills, and social skills, through its team-based structure and focus on self-chosen real-world problems (Question 2). Finally, the expression of $21^{\text {st }}$-century skills in the Technion's Formula Student project increases students' motivation to participate because these skills enable students to fulfill the basic needs - autonomy, competence and relatedness - which are the drivers of intrinsic motivation (Question 3). Future studies should continue to explore this topic with other team-based student projects, such as Engineers without Borders.

\section{Acknowledgements}

We thank the Technion's Bernard M. Gordon Center for System Engineering for its generous support of the study presented in this paper.

We would like to thank the students, mentors, the Technion's Faculty of Mechanical Engineering and project supporters and collaborators for their dedication and on-going collaboration.

\section{References}

Assor, A. (2001). Fostering intrinsic motivation for school learning. In A. Kaplan and A. Assor (Eds.), Thinking Education: Motivation for Learning: New Conceptions of Motivation 20 (pp. 167-190). Jerusalem: Branco-Wise Institute (Hebrew).

Bandura, A. (1994). Self-efficacy. In R. J. Corsini (Ed.), Encyclopedia of psychology (2nd ed., Vol. 3, pp. 368-369). New York: Wiley.

Baxter, P., \& Jack, S. (2008). Qualitative case study methodology: Study design and implementation for novice researchers. The Qualitative Report, 13(4), 544-559.

Beddoes, K. D., Jesiek, B. K., \& Borrego, M. (2010). Identifying opportunities for collaborations in international engineering education research on problem-and project-based learning. Interdisciplinary Journal of Problem-based Learning, 4(2), 7-34. https://doi.org/10.7771/1541-5015.1142

Binkley, M., Erstad, O., Herman, J., Raizen, S., Ripley, M., Miller-Ricci, M., \& Rumble, M. (2012). Defining twenty-first century skills. In Assessment and teaching of 21st century skills (pp.17-66). Netherlands: Springer. http://dx.doi.org/10.1007/978-94-007-2324-5_2

Borrego, M., Douglas, E. P., \& Amelink, C. T. (2009). Quantitative, qualitative, and mixed research methods in engineering education. Journal of Engineering Education, 98(1), 53-66. https://doi.org/10.1002/j.2168-9830.2009.tb01005.x

Bullen, F., \&Karri, V. (2002). Design and construction of a Formula SAE racecar in a teaching and research framework. HERDSA 2002, 74-83. http://citeseerx.ist.psu.edu/viewdoc/download?doi=10.1.1.111.6988\&rep=rep1\&type=pdf

Butterfield, A., \& Branch, K. J. (2016). Collaboration between seniors and freshmen on senior capstone projects. ASEE's $123^{\text {rd }}$ Annual Conference \& Exposition, New Orleans, LA, June 26-29. Paper ID \# 15618. https://doi.org/10.18260/p.26506

Casner-Lotto, J., \& Barrington, L. (2006). Are They Really Ready to Work? Employers' Perspectives on the Basic Knowledge and Applied Skills of New Entrants to the 21st Century US Workforce. Consortium of The Conference Board, Corporate Voices for Working Families, the Partnership for 21st Century Skills, and the Society for Human Resource Management. Retrieved from https://files.eric.ed.gov/fulltext/ED519465.pdf 
Cobb, C. L., Agogino, A. M., Beckman, S. L., \& Speer, L. (2008). Enabling and characterizing twenty-first century skills in new product development teams. International Journal of Engineering Education, 24(2), 420-433

Duderstadt, J. J. (2010). Engineering for a changing world: A roadmap to the future of American engineering practice, research, and education. In D. Grasso and M. B. Burkins (Eds), Holistic Engineering Education: Beyond Technology. New York: Springer, pp. 17-39. https://doi.org/10.1007/978-1-4419-1393-7_3

Dym, C. L., Agogino, A. M., Eris, O., Frey, D. D., \& Leifer, L. J. (2005). Engineering design thinking, teaching, and learning. Journal of Engineering Education, 94, 103-120. https://doi.org/10.1002/j.2168-9830.2005.tb00832.x

Gaffney, E. F., \& Salinas, A. R. (1997). Introduction to Formula SAE® Suspension and Frame Design. SAE Technical Paper No. 971584. https://doi.org/10.4271/971584

Grant, M. M. (2011). Learning, beliefs, and products: Students' perspectives with project-based learning. Interdisciplinary Journal of Problem-based Learning, 5(2), https://doi.org/10.7771/1541-5015.1254

Great Schools Partnership. Glossary of education reform, http://edglossary.org/project-based-learning/. Accessed 26 August 2014.

Greenhill, V. (2010). 21st Century Knowledge and Skills in Educator Preparation. Collaborative project by the American Association of Colleges of Teacher Education and the Partnership for 21st Century Skills (P21). Retrieved from http://www.p21.org/storage/documents/aacte_p21_whitepaper2010.pdf

Gruner, A. (2014). Organizing a Formula SAE® Team. Retrieved from_ http://students.sae.org/cds/formulaseries/fsae/reference/orgteam01.htm

Hidi, S., \& Harackiewicz, J. M. (2000). Motivating the academically unmotivated: A critical issue for the 21st century. Review of Educational Research, 70(2), 151-179. https://doi.org/10.3102/00346543070002151

Jones, B. D., Epler, C. M., Mokri, P., Bryant, L. H., \& Paretti, M. C. (2013). The effects of a collaborative problem-based learning experience on students' motivation in engineering capstone courses. Interdisciplinary Journal of Problem-based Learning, 7(2), 34-71. https://doi.org/10.7771/1541-5015.1344

Koh, C., Tan, H. S., Tan, K. C., Fang, L., Fong, F. M.,... \& Wee, M. L. (2010). Investigating the Effect of 3D Simulation Based Learning on the Motivation and Performance of Engineering Students. Journal of Engineering Education, 99(3), 237-251. https://doi.org/10.1002/j.2168-9830.2010.tb01059.x

Krapp, A. (2005). Basic needs and the development of interest and intrinsic motivational orientations. Learning and Instruction, 15(5), 381-395. https://doi.org/10.1016/j.learninstruc.2005.07.007

Linnenbrink, E. A., \& Pintrich, P. R. (2002). Motivation as an enabler for academic success. School Psychology Review, 31(3), 313-327.

Male, S. A., Bush, M. B., \& Chapman, E. S. (2010). Perceptions of competency deficiencies in engineering graduates. Australasian Journal of Engineering Education, 16(1), 55-67. https://doi.org/10.1080/22054952.2010.11464039

Marra, R. M., Chia-Lin, T., Bogue, B., \& Pytel, J. L. (2015). Alternative Pathways to Engineering Success-Using Academic and Social Integration to Understand Two-Year Engineering Student Success. American Journal of Engineering Education, 6(2), 69-83. https://doi.org/10.19030/ajee.v6i2.9503

Marra, R. M., Rodgers, K. A., Shen, D., \& Bogue, B. (2012). Leaving engineering: A multi - year single institution study. Journal of Engineering Education, 101(1), 6-27. https://doi.org/10.1002/j.2168-9830.2012.tb00039.x

Merriam, S. B. (2002). Introduction to qualitative research. In S. B. Merriam \& Associates, Qualitative Research in Practice (pp. 3-17). San Francisco, CA: Jossey-Bass,.

Niemiec, C. P., \& Ryan, R. M. (2009). Autonomy, competence, and relatedness in the classroom Applying self-determination theory to educational practice. Theory and Research in Education, 7(2), 133-144. https://doi.org/10.1177/1477878509104318

Pellegrino, J. W., \& Hilton, M. L. (Eds.). (2012). Education for Life and Work: Developing Transferable Knowledge and Skills in the 21st Century. National Academies Press, Washington DC.

Pintrich, P. R. (2004). A conceptual framework for assessing motivation and self-regulated learning in college 
students. Educational Psychology Review, 16(4), 385-407. https://doi.org/10.1007/s10648-004-0006-x

Pintrich, P. R. (2003). A motivational science perspective on the role of student motivation in learning and teaching contexts. Journal of Educational Psychology, 95(4), 667-686.

http://dx.doi.org/10.1037/0022-0663.95.4.667

Ricks, K. G., Richardson, J. A., Stern, H. P., Taylor R. P., \& Taylor, R. A. (2014). An engineering learning community to promote retention and graduation of at-risk engineering students. American Journal of Engineering Education, 5(2), 73-90. https://doi.org/10.19030/ajee.v5i2.8953

Ryan, R. M., \& Deci, E. L. (2000a). Intrinsic and extrinsic motivations: Classic definitions and new directions. Contemporary Educational Psychology, 25(1), 54-67. https://doi.org/10.1006/ceps.1999.1020

Ryan, R. M., \& Deci, E. L. (2000b). Self-determination theory and the facilitation of intrinsic motivation, social development, and well-being. American Psychologist, 55(1), 68-78. https://doi.org/10.1037/0003-066X.55.1.68

Thomas, J. W. (2000). A review of research on project-based learning. Retrieved from http://www.bie.org/index.php/site/RE/pbl_research/29

Tuchscherer, R. G., Gray, R., \& Gray, C. A. (2017). Board\# 145: Reshaping Engineering Classroom Norms to Expand the Profession. ASEE Annual Conference \& Exposition, June 2017. https://doi.org/10.18260/1-2--27763

Vansteenkiste, M., Lens, W., \& Deci, E. L. (2006). Intrinsic versus extrinsic goal contents in self-determination theory: Another look at the quality of academic motivation. Educational Psychologist, 41(1), 19-31. https://doi.org/10.1207/s15326985ep4101_4

Yin, R. K. (2013). Case Study Research: Design and Methods. Sage publications.

\section{Notes}

Note 1. The SAE's Formula SAE was established as a student competition in the United States in 1981. In 1998 the Institution of Mechanical Engineers accepted management of a European version of the event in partnership with the SAE under the name Formula Student.

\section{Copyrights}

Copyright for this article is retained by the author(s), with first publication rights granted to the journal.

This is an open-access article distributed under the terms and conditions of the Creative Commons Attribution license (http://creativecommons.org/licenses/by/4.0/). 